\title{
CHILDREN'S COMPETENCE TO TESTIFY IN AUSTRALIAN COURTS: IMPLEMENTING THE ROYAL COMMISSION RECOMMENDATION
}

\author{
SONJA P BRUBACHER, * NATALIE HODGSON, ** JANE GOODMAN- \\ DELAHUNTY,*** MARTINE B POWELL**** AND NINA WESTERA*****
}

In 2017, the Royal Commission into Institutional Responses to Child Sexual Abuse recommended reforms to the law of competence of child witnesses. We examined Australian judges' practices in assessing children's competence to give sworn evidence. Trial transcripts from 56 victims revealed that $64 \%$ were posed competence questions, with fewer to older children. The most frequent manner of posing such questions was to ask children to evaluate the morality of truths and lies. Most questions were yes/no format, and children nearly always answered these satisfactorily. When questions were 'wh-' format, children provided a satisfactory response only 51\% of the time. Only nine children testified unsworn, and they were asked more than twice as many competence questions as sworn children. Competence inquiries have been challenged for underestimating children's abilities, and because responses to questions about truths and lies are not predictive of behaviour. We discuss how reforms could be implemented.

\section{INTRODUCTION}

In 2017, the Royal Commission into Institutional Child Sexual Abuse ('Royal Commission') published its Criminal Justice Report ('Report'). ${ }^{1}$ The Report contained 85 recommendations designed to ensure that the criminal justice system operates in the interests of justice for society, the complainant and the accused, that criminal justice responses are available for victims and survivors, and that

\footnotetext{
* $\quad$ Research Fellow, Centre for Investigative Interviewing, Griffith Criminology Institute, Griffith University.

** PhD Candidate, Faculty of Law, UNSW Sydney.

*** Research Professor, School of Psychology, Charles Sturt University.

**** Professor, Centre for Investigative Interviewing, Griffith Criminology Institute, Griffith University.

***** Research Fellow, Griffith University (deceased, May 2017).

The preparation of this article was supported in part by a Royal Commission Grant to the three last authors.

1 Royal Commission into Institutional Responses to Child Sexual Abuse (Criminal Justice Report, August 2017).
} 
victims and survivors are supported in seeking criminal justice responses. ${ }^{2}$ Recommendation 62 concerned children's competence to give evidence in court. ${ }^{3}$ The Royal Commission recommended that simple, non-theoretical questions be used to establish a witness' competence and that witnesses who were not competent to give sworn evidence be asked to 'promise' to tell the truth as the requirement for giving unsworn evidence.

Historically, courts have been wary of the evidence given by child witnesses. ${ }^{4}$ Two key reasons underpinned this wariness. First, child witnesses were thought to be inherently unreliable, suggestible and prone to false allegations, particularly in cases of sexual abuse. Second, the evidence of child witnesses was further disregarded due to their inability to demonstrate an understanding of the nature and consequences of an oath. As such, for years, competence inquiries acted as an initial, critical obstacle preventing children from giving their evidence in court.

In recent years, reforms have sought to address the obstacle posed by competence requirements. In particular, the introduction of unsworn evidence has provided children with a greater opportunity to testify where they are unable to satisfy the competence standard for giving sworn evidence. However, questions remain about the extent to which the competence testing process is appropriate for children and whether it achieves its objective of promoting truthful testimony. The Royal Commission's recommendation sought to address these issues within the current competence regime.

In this article we discuss the Royal Commission's recommendation, focusing particularly on the issue of competence to give sworn and unsworn evidence (as compared to basic competence to testify). First, we provide an overview of psychological research on children's knowledge of truth and lies. Second, we outline the current law on competence in all Australian jurisdictions. Third, we discuss the Royal Commission's recommendation, highlighting areas of uncertainty for its implementation. Fourth, we provide the results of a study into current approaches taken by judges to assess children's competence to testify. In light of these findings, we provide further advice on how the Royal Commission's recommendation should be implemented.

\section{PSYCHOLOGICAL RESEARCH ON CHILDREN'S KNOWLEDGE OF TRUTH AND LIES}

Children begin developing knowledge of truth and lies at an early age. From as young as two years of age, children begin telling rudimentary fibs and can

2 Ibid Executive Summary and pts I-II, 3.

3 Ibid pts VII-X and apps, 103. Note that in this article, 'children' is generally used to refer to people under the age of 18 years, unless another age range is specified.

4 For a discussion see Michael Harris and Gregor Urbas, 'Children's Unsworn Evidence: Historical Developments and Contemporary Issues’ (2017) 40(4) University of New South Wales Law Journal 1392. 
identify and reject simple yes/no statements that are clearly false. ${ }^{5}$ Around age three, they come to understand that it is morally wrong to lie. ${ }^{6}$ Children under four or five years of age struggle to maintain lies over a short period of time or in response to different types of questions, ${ }^{7}$ but this ability steadily improves through middle childhood (the period from ages six to 12) in tandem with other cognitive developments, such as theory of mind awareness (understanding that the actions of others are motivated by beliefs, intentions, and knowledge) ${ }^{8}$ and executive function (the cognitive processes facilitating goal-directed behaviour). ${ }^{9}$ Throughout middle childhood, children's lies become more complex and stable. ${ }^{10}$ That a child is capable of lying or telling the truth, however, means neither that he or she will do so, nor that the child can answer challenging questions about the meaning of these abstract concepts.

Psychological research suggests that some questions are more developmentally appropriate for young children than others. In particular, children's abilities to answer questions where they are required to identify a statement as a truth or a lie improves markedly between the ages of four to seven years old. ${ }^{11}$ However, children may still make errors in answering such questions, as they may misunderstand the purpose of the question or be required to call the questioner a liar in order to answer the question correctly..$^{12}$ Less developmentally appropriate questions for children are those asking for the definitions of terms such as an 'oath', and questions requiring children to explain the difference between truth and lies. ${ }^{13}$ This is because children need an abstract understanding of the proper use of the word to answer the question correctly, which can prove challenging when the word itself represents an abstract concept rather than an object. When children are asked questions about the consequences of lying, research indicates that they are more likely to provide accurate responses if asked about consequences to a hypothetical protagonist rather than to themselves. ${ }^{14}$ This is likely because of an association between lying and 'badness'. A potential consequence of asking less appropriate questions is underestimation of the ability

Peter Hummer, Heinz Wimmer and Gertraud Antes, 'On the Origins of Denial Negation' (1993) 20(3) Journal of Child Language 607.

6 Kang Lee, 'Little Liars: Development of Verbal Deception in Children' (2013) 7(2) Child Development Perspectives 91 .

7 Victoria Talwar and Kang Lee, 'Development of Lying to Conceal a Transgression: Children's Control of Expressive Behaviour During Verbal Deception' (2002) 26(5) International Journal of Behavioral Development 436; Angela D Evans and Kang Lee, ‘Emergence of Lying in Very Young Children’ (2013) 49(10) Developmental Psychology 1958.

$8 \quad$ Henry M Wellman, The Child's Theory of Mind (MIT Press, 1991) ch 3.

9 Stephanie M Carlson, Louis J Moses and Hollie R Hix, 'The Role of Inhibitory Processes in Young Children's Difficulties with Deception and False Belief’ (1998) 69(3) Child Development 672, 686.

10 Lee (n 6)

11 Thomas D Lyon and Karen J Saywitz, 'Young Maltreated Children's Competence to Take the Oath' (1999) 3(1) Applied Developmental Science 16.

12 For example, 'If I was to say my hair is green, would that be a truth or a lie?' See ibid; Thomas D Lyon et al, 'Reducing Maltreated Children's Reluctance to Answer Hypothetical Oath-Taking Competency Questions' (2001) 25(1) Law and Human Behavior 81.

13 Lyon and Saywitz (n 11).

14 Lyon et al (n 12). 
of the child who may be deemed to not satisfy competence requirements purely because the test consisted of inappropriate questions.

Differences in question format further complicate matters. Two key question formats are recall-based questions ('wh-' questions, for example, 'What does it mean to tell the truth?') and recognition-based questions, which include a forced choice between options posed in the question (such as, 'Is that true or is it a lie?') and yes/no questions (where the forced choice is yes or no). Recall-based questions provide the best assessment of knowledge, because respondents are required to generate an answer rather than select one from options posed to them.${ }^{15}$ However, children often find these questions more difficult to answer. In contrast, recognition questions are easier to answer and can be appropriate for very young children. ${ }^{16}$ However, if a child does not understand a recognition question, he or she is unlikely to ask for clarification and will instead guess the answer or, among younger children, simply assent. ${ }^{17}$ Accordingly, the form of the questions used to determine the child's understanding of truth and lies may impact their ability to demonstrate their competence; that is, the way in which a competence test is administered may affect the outcome of the test. ${ }^{18}$

Notwithstanding that competence questions themselves are inherently problematic, a large corpus of evidence supports the claim that children's understanding of or ability to explain the meaning of truths and lies does not predict their likelihood of telling the truth. ${ }^{19}$ By comparison, courts never assume that an adult's ability to distinguish between truth and lies is predictive of their propensity to tell the truth; in $R J v$ The Queen, Campbell JA noted that '[m]any a lying witness, and many an unreliable witness, has the capacity to understand that he or she is under that sort of an obligation (and thus is competent to give sworn

15 Fergus IM Craik and Robert S Lockhart, 'Levels of Processing: A Framework for Memory Research' (1972) 11(6) Journal of Verbal Learning and Verbal Behavior 671.

16 Nicholas Bala et al, 'The Competency of Children to Testify: Psychological Research Informing Canadian Law Reform' (2010) 18(1) International Journal of Children's Rights 53, 63; Thomas D Lyon, 'Assessing the Competency of Child Witnesses: Best Practice Informed by Psychology and Law' in Michael E Lamb et al (eds), Children's Testimony: A Handbook of Psychological Research and Forensic Practice (Wiley-Blackwell, $2^{\text {nd }}$ ed, 2011) 69.

17 Amanda H Waterman, Mark Blades and Christopher Spencer, 'Interviewing Children and Adults: The Effect of Question Format on the Tendency to Speculate' (2001) 15(5) Applied Cognitive Psychology 521, 522-3.

18 Patrick Parkinson, 'The Future of Competency Testing for Child Witnesses' (1991) 15(3) Criminal Law Journal 186, cited in $R v R A G$ [2006] NSWCCA 343, [44] (Latham J, McClellan CJ at CL agreeing at [1], Johnson J agreeing at [2]). See also the findings of Cashmore and Bussey where an analysis of transcripts revealed 'considerable variability' in the difficulty of the questions used to assess competence testing: Judy Cashmore and Kay Bussey, 'Judicial Perceptions of Child Witness Competence' (1996) 20(3) Law and Human Behavior 313, 328.

19 Gail S Goodman, Christine Aman and Jodi Hirshman, 'Child Sexual and Physical Abuse: Children's Testimony' in Stephan J Ceci, Michael P Toglia, and David F Ross (eds), Children's Eyewitness Memory (Springer-Verlag, 1987) 1, 17-18; Kamala London and Narina Nunez, 'Examining the Efficacy of Truth/Lie Discussions in Predicting and Increasing the Veracity of Children's Reports' (2002) 83(2) Journal of Experimental Child Psychology 131; Margaret-Ellen Pipe and J Clare Wilson, 'Cues and Secrets: Influences on Children's Event Reports' (1994) 30(4) Developmental Psychology 515; Victoria Talwar et al, 'Children's Conceptual Knowledge of Lying and Its Relation to Their Actual Behaviours: Implications for Court Competence Examinations' (2002) 26(4) Law and Human Behavior 395. 
evidence), even though he or she in fact does not give truthful evidence'. ${ }^{20}$ The irony of the prevailing competency test is that older children with more advanced cognitive abilities who can better answer competence questions are also those who are more able to lie. ${ }^{21}$

Some research indicates that asking a child to promise to tell the truth may promote truth-telling behaviour. ${ }^{22}$ For the promise to be effective, children are generally required to have a basic understanding of 'the truth', which it is believed most do before they reach the age of four. ${ }^{23}$ However, the literature supporting the use of the promise with younger (preschool) aged children is somewhat mixed, with some studies indicating that this strategy may be ineffective or less effective at younger (preschool) ages, ${ }^{24}$ whereas another study showed that a promise to tell the truth decreased dishonesty even among children who would fail an oath-taking competence assessment. ${ }^{25}$ Accordingly, developmental psychologists have recommended eliminating truth/lie competence testing entirely and instead suggest that children simply be asked, 'Do you promise that you will tell the truth?'26 This is the approach currently taken in Canada (discussed below) ${ }^{27}$ and Scotland..$^{28}$

\section{COMPETENCE TESTING IN AUSTRALIA}

\section{A Historical Overview of Competence Testing}

The requirement to testify under oath has long been a feature of jury trials. ${ }^{29}$ In the case of $R v$ Brasier, the Court held that 'no testimony whatever can be legally received except upon oath' ${ }^{30}$ For a witness to give sworn evidence, he or she needed to demonstrate 'sufficient knowledge of the nature and consequences of an oath ... their admissibility depends upon the sense and reason they entertain of the

20 (2010) A Crim R 174, 180 [20].

21 Angela D Evans and Kang Lee, 'Verbal Deception from Late Childhood to Middle Adolescence and Its Relation to Executive Functioning Skills' (2011) 47(4) Developmental Psychology 1108.

22 Thomas D Lyon and Joyce S Dorado, 'Truth Induction in Young Maltreated Children: The Effects of Oath-Taking and Reassurance on True and False Disclosures' (2008) 32(7) Child Abuse \& Neglect 738; Thomas D Lyon et al, 'Coaching, Truth Induction, and Young Maltreated Children's False Allegations and False Denials’ (2008) 79(4) Child Development 914; Talwar et al (n 19) 408.

23 Thomas D Lyon, Jodi A Quas and Nathalie Carrick, 'Right and Righteous: Children's Incipient Understanding and Evaluation of True and False Statements' (2013) 14(3) Journal of Cognition and Development $437,439$.

24 Jasmine Bender, Alison M O'Connor and Angela D Evans, 'Mirror, Mirror on the Wall: Increasing Young Children's Honesty Through Inducing Self-Awareness' (2018) 167 Journal of Experimental Child Psychology 414, 418-19; Jodi A Quas, Stacia N Stolzenberg and Thomas D Lyon, 'The Effects of Promising to Tell the Truth, the Putative Confession, and Recall and Recognition Questions on Maltreated and Non-Maltreated Children's Disclosure of a Minor Transgression' (2018) 166 Journal of Experimental Child Psychology 266, 273, 275.

25 Talwar et al (n 19) 411-12.

26 Thomas D Lyon, 'Interviewing Children' (2014) 10 Annual Review of Law and Social Science 73, 75.

27 Canada Evidence Act, RSC 1985, c C-5, s 16.1(6).

28 Vulnerable Witnesses (Scotland) Act 2004 (Scot) s 24.

29 Harris and Urbas (n 4) 1397-405.

30 (1779) 1 Leach 199; 168 ER 202, 202. 
danger and impiety of falsehood' ${ }^{31}$ This requirement often meant demonstrating religious knowledge and a belief in God's divine vengeance in addition to a general knowledge of truth and lies..$^{32}$ These requirements posed a number of obstacles for children, who struggled to define and articulate complex adult concepts. The introduction of the affirmation enabled witnesses to testify who did not have a belief in a religious being. ${ }^{33}$ While this was primarily directed at facilitating adult testimony, ${ }^{34}$ it had the consequential effect of broadening the possibilities for children to testify. ${ }^{35}$ Further, legal systems gradually began to entertain the possibility of unsworn testimony, providing an alternative avenue for witnesses who failed competence tests to give sworn evidence in court. ${ }^{36}$

\section{B The Current Law on Competence Testing - Uniform Evidence Law Jurisdictions}

Under the Uniform Evidence Law, there is a presumption in favour of the competence of a witness. ${ }^{37}$ When the competence of a witness is challenged, the first question for the court to consider is whether a witness has basic competence. A witness will not have basic competence to testify about a fact if the witness 'does not have the capacity to understand a question about the fact' or 'does not have the capacity to give an answer that can be understood to a question about the fact' and that incapacity cannot be overcome. ${ }^{38}$ If it is established that a witness does not have basic competence, ${ }^{39}$ he or she will not be permitted to testify. A witness may be competent to testify about some facts but not about others. ${ }^{40}$ Where the evidence is pre-recorded, the issue is whether the witness was competent at the time he or she gave evidence. ${ }^{41}$

Once the basic competence of a witness is established, the question arises as to whether the witness is competent to give sworn evidence. A witness will not be competent to give sworn evidence 'if the person does not have the capacity to understand that, in giving evidence, he or she is under an obligation to give truthful evidence'. ${ }^{42}$ This standard applies to all children; it is not a barrier to giving

Ibid 202-3.

Nicholas Bala, 'Canada's Empirically-Based Child Competency Test and its Principled Approach to Hearsay’ (2014) 19(2) Roger Williams University Law Review 513, 523; Karen Schultz, 'The Need for Competence Tests: Queensland Judicial Perspectives on Non-accused Child Witnesses in Criminal Proceedings, Part 1' (2003) 22(2) University of Queensland Law Journal 199, 202.

See, eg, Oaths Act 1900 (NSW) s 12.

See generally Harris and Urbas (n 4) 1400.

See, eg, $R v$ Peters (1882) 3 LR (NSW) 455, 458-9 (Faucett J), 459 (Windeyer J).

See, eg, Child Welfare Act 1923 (NSW) s 110, as repealed by Child Welfare Act 1939 (NSW); Oaths (Children) Amendment Act 1985 (NSW), inserting Oaths Act 1900 (NSW) s 33.

Evidence Act 1995 (Cth) s 12; Evidence Act 2011 (ACT) s 12; Evidence Act 1995 (NSW) s 12; Evidence (National Uniform Legislation) Act 2011 (NT) s 12; Evidence Act 2001 (Tas) s 12; Evidence Act 2008

(Vic) s 12. When citing provisions of the Uniform Evidence Law, all future references will refer to the Commonwealth Act only.

Evidence Act 1995 (Cth) s 13(1).

The relevant standard is on the balance of probabilities: ibid s 142(1).

Ibid s 13(2).

Tikomaimaleya $v$ The Queen (2017) 95 NSWLR 315, 325 [56] (Simpson JA).

Evidence Act 1995 (Cth) s 13(3). 
evidence that a child is under the age of 10 and thus cannot be held criminally responsible for giving false testimony ${ }^{43}$ The term 'obligation' has 'its ordinary, grammatical meaning as the condition of being morally or legally bound' ${ }^{44}$ The court must be satisfied that the witness does not have the capacity to understand the obligation, rather than not being satisfied that the witness does have the capacity to understand the obligation. ${ }^{45}$ The question of competence is to be determined on the balance of probabilities. ${ }^{46}$

The competence inquiry should be framed in a way that young children, with their limited language skills, can understand. ${ }^{47}$ It may involve questions relating to a child's education, interests, ability to understand different types of questions, understanding of why the child is giving evidence and what is expected of them, and knowledge of what will happen if he or she does not give truthful evidence..$^{48}$ A child's affirmative answer to the question, '[D]o you understand that today in giving evidence you have to only tell us the truth? You have to tell us things that really happened, you understand that?' does not necessarily establish that child's capacity to understand their obligation to give truthful evidence. ${ }^{49}$

Where a witness demonstrates basic competence, but is not competent to give sworn evidence, the witness will be competent to give unsworn evidence.$^{50}$ All that is required for a witness to testify unsworn is that the witness is competent within the meaning of section 13(1) and the court has told the witness of the matters in section 13(5):

(a) that it is important to tell the truth; and

(b) that he or she may be asked questions that he or she does not know, or cannot remember, the answer to, and that he or she should tell the court if this occurs; and

(c) that he or she may be asked questions that suggest certain statements are true or untrue and that he or she should agree with the statements that he or she believes are true and should feel no pressure to agree with statements that he or she believes are untrue. ${ }^{51}$

$43 \quad R v$ Cooper (2007) 214 FLR 92, 99 [42]-[43] (Higgins CJ).

$44 \quad R v G W(2016) 258$ CLR 108, 122 [26] (French CJ, Bell, Gageler, Keane and Nettle JJ).

45 Ibid 122-3 [28].

46 Evidence Act 1995 (Cth) s 142(1); RA v The Queen (2007) 175 A Crim R 221, 224 [11] (McClellan CJ at $\mathrm{CL}$, Howie J agreeing at 225 [15], Harrison J agreeing at 225 [16]), cited in $R J v$ The Queen (2010) $208 \mathrm{~A}$ Crim R 174, 181 [24] (Campbell JA).

$47 R v R A G$ [2006] NSWCCA 343, [25]-[27], [43]-[45] (Latham J, McClellan CJ at CL agreeing at [1], Johnson J agreeing at [2]).

48 Ibid [26]. See further Law Reform Commission, Evidence (Report No 26, 1985) 286 [522]; Judicial Commission of New South Wales, Equality before the Law Bench Book (2018) 6.3.2

$<$ https://www.judcom.nsw.gov.au/publications/benchbks/equality/>.

$49 R v G W(2016) 258$ CLR 108, 122 [26] (French CJ, Bell, Gageler, Keane and Nettle JJ).

$50 \quad$ Evidence Act 1995 (Cth) s 13(5).

51 The directions are not required to be in a particular format, but they must give effect to the terms of ss 13(5)(a)-(c): SH v The Queen (2012) 83 NSWLR 258, 264 [22] (Basten JA, Blanch J agreeing at 267 [36], Hall J agreeing at 267 [37]). The giving of these instructions may occur in the context of setting communication ground rules for a trial. Note that ground rules extend beyond these competence questions: in a study of Australian child sexual abuse trials, 11 different types of ground rules were distinguished: Becky Earhart et al, 'Judges' Delivery of Ground Rules to Child Witnesses in Australian Courts' (2017) 74 Child Abuse \& Neglect 62. The core ground rules aim to encourage children to speak up if they do not understand a question, do not know the answer, or cannot recall. 
By telling a witness these matters, the court creates the "condition of competence'. ${ }^{52}$ This provision only requires that the directions be given; it is not necessary that they be understood or even acknowledged..$^{53}$ Accordingly, the process prescribed by section 13(5) does not require the court to test the witness' understanding of the directions. Because of this, in the case of $R v$ Muller, the Australian Capital Territory Court of Appeal held that a child's response of 'I don't know' to the question, '[W] hat do you understand by me telling you that it is important to tell the truth? What does that mean to you?' was 'irrelevant' to the question of the child's competence to give unsworn evidence. ${ }^{54}$ However, in that same case Penfold J suggested that it was not undesirable 'for a judge to try to ensure that the proposed witness has understood the directions given under s 13(5)' so long as the judge recognises that an absence of such an understanding does not prevent a witness from being able to testify unsworn. ${ }^{55}$

In the case of $R v G W,{ }^{56}$ the High Court was asked to consider whether a direction should have been given to the jury regarding the unsworn evidence of a child. The Australian Capital Territory Court of Appeal had held that the trial judge was required to instruct the jury on the difference between sworn and unsworn evidence and that the jury should take that difference into account in assessing the reliability of the unsworn evidence..$^{57}$ This was overturned by the High Court, which held that:

As a matter of practical reality, neither the fact that [the child] did not take an oath or make an affirmation before giving her evidence, nor that she was not subject to the sanctions that may apply to the failure to adhere to the oath or affirmation, was material to the assessment of whether [her] evidence was truthful and reliable such that the jury could accept and act upon it..$^{58}$

As such, where unsworn evidence is given by a child, there is no requirement that a direction be given, either that the (unsworn) evidence is of a type that may be unreliable, ${ }^{59}$ or that the jury should take into account the differences between sworn and unsworn evidence in assessing the reliability of the child's evidence. Although no previous jurisprudence was referred to by the High Court, it has been suggested that this decision reversed a previous practice of seeking such a direction where a child testified unsworn. ${ }^{60}$ Accordingly, under the present law it may be of

52 SH v The Queen (2012) 83 NSWLR 258, 263 [19] (Basten JA, Blanch J agreeing at 267 [36], Hall J agreeing at 267 [37]).

$53 \quad R v$ Muller (2013) 7 ACTLR 296, 313 [44] (Dowsett J, Penfold J agreeing at 297 [1], Nield AJ agreeing at 314 [49]).

54 Ibid 313-14 [45]-[46].

$55 \operatorname{Ibid} 297[3]$.

56 (2016) 258 CLR 108.

57 Ibid 114-15 [4] (French CJ, Bell, Gageler, Keane and Nettle JJ).

58 Ibid 132 [54].

59 Note that warnings about the unreliability of children's evidence in general are prohibited under the Evidence Act 1995 (Cth) s 165A(1), although a judge may give a warning about the reasons why a particular child's evidence might be unreliable under s $165 \mathrm{~A}(2)$.

60 'Unsworn v Sworn Evidence in Court', The Law Report (ABC Radio National, 8 March 2016)

$<$ http://www.abc.net.au/radionational/programs/lawreport/unsworn-v-sworn-evidence-incourt/7226444>. 
little consequence whether a child gives sworn or unsworn evidence so long as the correct procedural prerequisites have been satisfied.

\section{The Current Law on Competence Testing - Other Jurisdictions}

Queensland, South Australia and Western Australia apply their own evidence law. In Queensland, there is a presumption in favour of the competence of a witness. ${ }^{61}$ Where an issue is raised about the competence of a witness, a witness will have basic competence to give evidence if he or she is able to give an intelligible account of events which he or she has observed or experienced' ${ }^{62}$ This refers to the capacity of the person to be understood, rather than their account being truthful or accurate. ${ }^{63}$

A witness will be competent to give sworn evidence if the witness understands that the giving of evidence is a serious matter and that he or she has an obligation to tell the truth in giving evidence that is over and above the ordinary duty to tell the truth. ${ }^{64}$ This test is derived from the test in $R v$ Hayes which examined whether 'the child has a sufficient appreciation of the solemnity of the occasion, and the added responsibility to tell the truth, which is involved in taking an oath, over and above the duty to tell the truth which is an ordinary duty of normal social conduct'. ${ }^{65}$ A witness who is not competent to give sworn evidence will be competent to give unsworn evidence if the court explains to the person the duty of speaking the truth. ${ }^{66}$ In $R v M B T$, this requirement was satisfied where the trial judge told the child that it was important for her to tell the truth, that she could get into trouble if she told a lie and asked her to promise to tell the truth. ${ }^{67}$ The probative value of this evidence is not decreased by virtue of the fact that the evidence is not given on oath. ${ }^{68}$ In this sense, Queensland is similar to the Uniform Evidence Law jurisdictions, as it is of little consequence whether a child gives sworn or unsworn evidence so long as the correct procedural prerequisites have been satisfied.

In South Australia, there is a presumption that a witness is competent to give sworn evidence. ${ }^{69}$ This presumption will be displaced where a judge finds that the witness 'does not have sufficient understanding of the obligation to be truthful entailed in giving sworn evidence'.$^{70}$ This is not an inquiry into the witness' understanding of an oath or affirmation; rather, it is an inquiry into whether the witness has a sufficient understanding of the obligation to be truthful under an oath

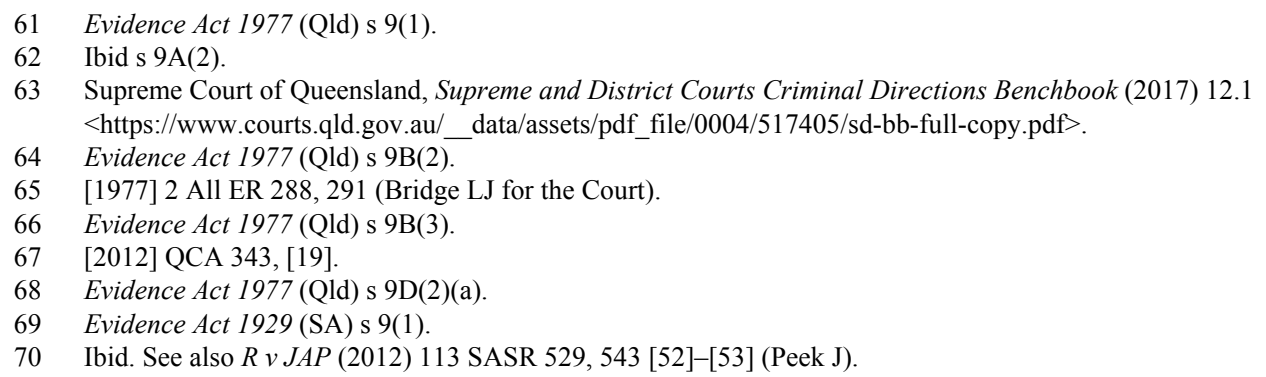


or affirmation..$^{71}$ The section has been interpreted as requiring an understanding that 'in giving sworn evidence, the person is thereby accepting the solemnity of the taking of an oath or the making of an affirmation and the sanctions which would follow, both morally and legally, if that person failed to comply with the obligation to tell the truth' ${ }^{72}$ As such, something more is needed than simply understanding the obligation to be truthful.

Where a witness cannot give sworn evidence, he or she will be permitted to give unsworn evidence if

(a) the judge-

(i) is satisfied that the person understands the difference between the truth and a lie; and

(ii) tells the person that it is important to tell the truth; and

(b) the person indicates that he or she will tell the truth. ${ }^{73}$

Accordingly, in contrast to the Uniform Evidence Law jurisdictions and Queensland where a witness will be permitted to give unsworn evidence when he or she has been instructed as to certain matters, South Australia imposes stricter obligations, requiring that the witness demonstrate an understanding of the difference between truth and lies and indicate their willingness to tell the truth.

Where a witness gives unsworn evidence, the judge must explain to the jury the reason that the evidence is unsworn. ${ }^{74}$ As part of this, the judge must tell the jury that he or she had found that the witness did not have a sufficient understanding of the obligation to be truthful entailed in giving sworn evidence and explain what that meant. ${ }^{75}$ Further, the judge "may, and if a party so requests must', warn a jury of the need for caution in determining whether to accept the evidence and the weight to be given to it. ${ }^{76}$ This includes telling the jury that, because the evidence is unsworn, they should use caution when deciding whether or not to accept the evidence and, if they do accept it, the weight to be given to it. ${ }^{77}$ In this sense, the position in South Australia is that the fact that a witness gives unsworn evidence goes to the reliability and credibility of their evidence. ${ }^{78}$ Hence, South Australia retains a distinction between the weight to be given to sworn and unsworn evidence that does not exist in the Uniform Evidence Law jurisdictions and Queensland.

In Western Australia, different laws apply depending on whether the witness is under the age of 12 or aged 12 and over. If the witness is aged 12 or over, he or

$R v$ Climas (1999) 74 SASR 411, 416-17 [24] (Duggan J, Millhouse J agreeing at 412 [1]), citing $R v$ Whittingham (1988) 49 SASR 67, 69 (King CJ, Prior J agreeing at 74).

72 Ibid 431 [137] (Lander J, Millhouse J agreeing at 412 [1]). Note that while a child under the age of 10 cannot be guilty of giving false evidence, they may have a sufficient understanding of the obligation to be truthful to give sworn evidence: at 419 [44] (Duggan J, Millhouse J agreeing at 412 [1]), 431-2 [137] (Lander J, Millhouse J agreeing at 412 [1]).

73 Evidence Act 1929 (SA) s 9(2).

74 Ibid s 9(4)(a).

$75 \quad R \vee J A P$ (2012) 113 SASR 529, 548-9 [75] (Peek J).

76 Evidence Act 1929 (SA) s 9(4)(b).

$77 R v$ French (2012) 114 SASR 287, 296 [34] (Sulan J, Gray J agreeing at 288 [1], White J agreeing at 297-8 [37]).

$78 \quad R \vee J A P(2012) 113$ SASR 529, 551 [91] (Peek J). 
she must give evidence on oath unless an exception applies. ${ }^{79}$ One such exception to giving sworn evidence exists where the witness 'does not understand the nature of, or the obligation imposed by, an oath or affirmation' ${ }^{80}$ In these circumstances, if the witness understands that he or she is required to speak the truth (and, where the witness is a compellable witness, to tell what he or she knows about the matter to which the testimony relates) and that the witness will be liable to punishment if he or she does not do so ${ }^{81}$ the evidence of that witness can be received unsworn where the court informs the witness that he or she is required to speak the truth (and, where the witness is a compellable witness, to tell what he or she knows about the matter in question) and that the witness will be liable to punishment if he or she does not do so. ${ }^{82}$ As such, the competence regime for witnesses aged 12 and over in Western Australia differs from the Uniform Evidence Law jurisdictions and Queensland, where witnesses do not need to demonstrate any positive understanding to testify unsworn, and the only condition required to testify unsworn is that they are told by a judge the importance of telling the truth.

A child under 12 years of age can give sworn evidence if the court is of the opinion that the witness understands that the giving of evidence is a serious matter and that he or she has an obligation to tell the truth while giving evidence ${ }^{83}$ If the witness is not competent to give sworn evidence, he or she will be permitted to give unsworn evidence if the court is of the opinion that the witness is able to give an 'intelligible account of events which he or she has observed or experienced' ${ }^{84}$ The intelligibility of a witness' account does not concern its accuracy or reliability; the fact that a witness answers questions incorrectly does not preclude them from giving an intelligible account of events. ${ }^{85}$ There is no requirement that a witness be directed as to the importance of telling the truth; in this sense, the procedure in Western Australia for witnesses aged under 12 differs from the other jurisdictions in Australia.

Where the witness is aged 12 and over and gives evidence unsworn, the fact that the evidence is given unsworn is a relevant matter to be taken into account in assessing the weight and credibility to be given to the evidence, ${ }^{86}$ and a judge should direct the jury accordingly. ${ }^{87}$ In this sense, Western Australia retains a distinction between the weight to be given to sworn and unsworn evidence, similarly to South Australia. However, there is no general rule that less weight should be given to the unsworn evidence of witnesses under 12 years old, and no general rule that a warning should be given to the jury, ${ }^{88}$ although there may be

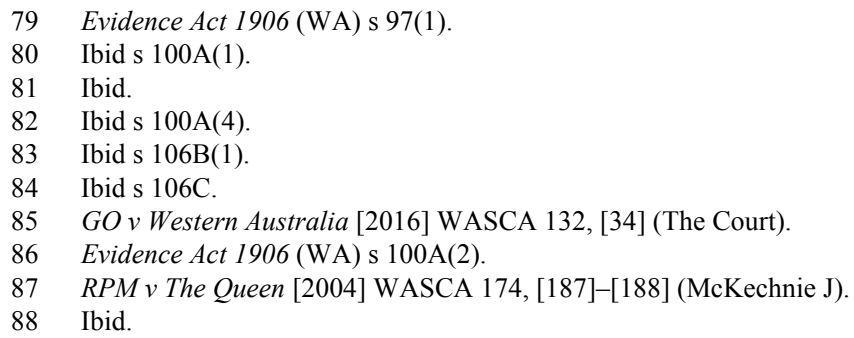


cases where specific facts justify the jury being directed as to certain matters. ${ }^{89} \mathrm{As}$ such, for witnesses under the age of 12 years old, the position is more similar to that of the Uniform Evidence Law jurisdictions and Queensland.

The similarities and differences between the jurisdictions regarding the tests for sworn and unsworn evidence are summarised in Table 1.

89 Ibid [137] (Wheeler J). For example, in RPM $v$ The Queen, Justice Wheeler found that the trial judge should have directed the jury about how the nature of the evidence (pre-recorded testimony out of court), the nature of the questioning (the use of leading questions) and the particular characteristics of the victim (a young Aboriginal child) could have affected the reliability of the statement, and told the jury that they should scrutinise the making of the statement with care, having regard to those factors, in determining the weight to give to that statement: at [137]. 


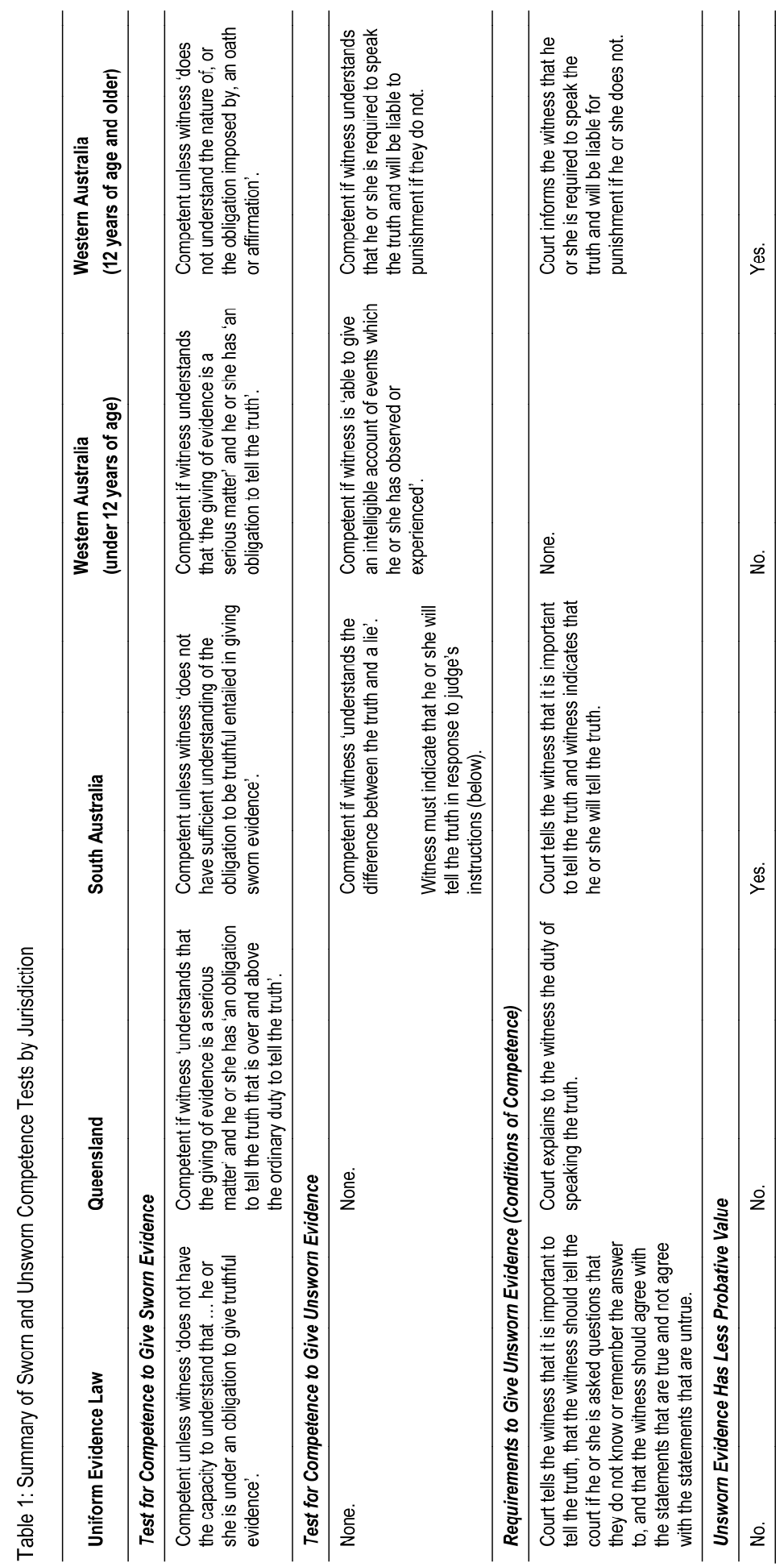




\section{The Royal Commission Recommendation}

In their Criminal Justice Report, the Royal Commission noted 'strong support for the view that the practice of questioning younger children on the difference between truth and lies is not effective in ensuring that the witness subsequently tells the truth' ${ }^{90}$ Recommendation 62 recommended changes to evidence law regarding children's competence:

62. State and territory governments should introduce legislation to allow a child's competency to give evidence in child sexual abuse prosecutions to be tested as follows:

(a) Where there is any doubt about a child's competence to give evidence, a judge should establish the child's ability to understand basic questions asked of them by asking simple, non-theoretical questions - for example, about their age, school, family et cetera.

(b) Where it does not appear that the child can give sworn evidence, the judge should simply ask the witness for a promise to tell the truth and allow the examination of the witness to proceed..$^{91}$

The Royal Commission's recommendation relates to two aspects of the competence inquiry. First, it concerns how a witness' basic competence to testify should be assessed. Second, it concerns the procedure to be followed when a witness is not competent to give sworn evidence. In this sense, the recommendation differs from the current law of all States and Territories, by (a) removing requirements that children demonstrate a certain level of knowledge or understanding to testify unsworn in those States that have such requirements, and (b) changing the condition of competence to be a promise to tell the truth. The recommendation is silent as to the rule existing in some States that unsworn evidence should be given less probative weight than sworn evidence.

The recommendation appears to retain a distinction between sworn and unsworn evidence, as it refers to the procedure to be adopted where a witness testifies unsworn. However, the recommendation is silent as to how the court will determine whether a witness is competent to give sworn evidence. Despite noting 'strong support for the view that the practice of questioning younger children on the difference between truth and lies is not effective in ensuring that the witness subsequently tells the truth', ${ }^{92}$ the Royal Commission does not discuss whether witnesses should continue to be questioned in such a manner or not. It is unclear whether the Royal Commissioners did not refer to this questioning process because they believed that it should be abolished, or because they believed that no changes should be made from the existing regime.

The procedure to be adopted in determining if a witness is competent to give sworn evidence is significant for a number of reasons. First and foremost, as the fact that evidence is unsworn can affect its probative value in some jurisdictions, it is imperative that children's competence to give sworn testimony is accurately assessed. More generally, the competence inquiry comprises the initial questioning to which the child is subjected. If children are asked complicated questions that 
they struggle to answer, they may feel confused and thus appear less credible before they have even begun to testify. ${ }^{93}$ As such, in reforming the law on competence to testify, significant thought should be given to how a child's competence to give sworn evidence is determined.

Not all countries require children to be questioned about truth and lies; some countries have abolished the practice. One such example is Canada. In 2006, Canada reformed its competence provisions to permit witnesses under 14 years of age to testify where they have basic competence; that is, where they have the capacity to 'understand and respond to questions' ${ }^{94}$ Instead of taking an oath or making a declaration, these witnesses must simply promise to tell the truth before testifying. ${ }^{95}$ Legislation expressly prohibits the court from questioning children regarding their understanding of the nature of the promise to tell the truth for the purpose of determining whether their evidence will be received. ${ }^{96}$ Evaluations of the reform showed that it 'clearly simplified and shortened the process of qualification for child witnesses', and in a significant proportion of cases the child was accepted as competent without inquiry. ${ }^{97}$

In the following Part we describe research conducted into the practices adopted by judges in questioning child witnesses to determine their competence to give sworn and unsworn evidence in three Australian jurisdictions. After presenting the findings of this research, we discuss the implications of these findings for implementing the Royal Commission's recommendation.

\section{JUDICIAL APPROACHES TO DETERMINING THE COMPETENCE OF CHILD WITNESSES}

This study was conducted as part of a larger project within the Royal Commission research program to evaluate justice practices in eliciting evidence from complainants of child sexual abuse.$^{98}$ It provides an overview of the practices used by judges in three Australian jurisdictions to assess children's competence to give sworn and unsworn evidence. The study aimed to identify the types of questions asked by Australian judges, of which children, and how children responded. It also aimed to determine how frequently best practice 'promise' questions were asked.

93 For example, see the concerns about intimidating the child raised in $R v R A G$ [2006] NSWCCA 343, [37]-[38] (Latham J, McClellan CJ at CL agreeing at [1], Johnson J agreeing at [2]).

94 Canada Evidence Act, RSC 1985, c C-5, s 16.1(3).

95 Ibid s 16.1(6).

96 Ibid s 16.1(7).

97 Nicholas Bala et al, Canadian Research Institute for Law and the Family, Testimonial Support Provisions for Children and Vulnerable Adults (Bill C-2): Case Law Review and Perceptions of the Judiciary (Report, 2008) viii-ix.

98 See Jane Goodman-Delahunty et al, 'Methods to Evaluate Justice Practices in Eliciting Evidence from Complainants of Child Sexual Abuse’ (2017) 12 Newcastle Law Review 42. 


\section{A Method}

\section{Sample}

As part of its research program, the Royal Commission obtained trial transcripts for 156 cases of contemporary and historical child sexual abuse in New South Wales ('NSW'), Victoria ('Vic') and Western Australia ('WA'). From these transcripts, cases were selected where the complainant was younger than 18 years of age at the time of the trial. This resulted in a final sample of 51 trials conducted between 2010 and 2015 involving 56 unique child complainants. All the alleged offences took place between 2000 and 2014.

The sample contained 15 male and 41 female complainants, aged 7.01 to 17.54 years with a mean age of 12.64 years $(S D=3.15)$. Table 2 provides an overview of complainant age in each jurisdiction. Children testifying in NSW were significantly younger than children in Vic, with children in WA not differing in age from those in the other two States. ${ }^{99}$

Table 2: Complainant Age by Jurisdiction (Years)

\begin{tabular}{llllll}
\hline Jurisdiction & $\boldsymbol{n}$ & $\boldsymbol{M}(\boldsymbol{S D})$ & Range & Median & \% 12 and Under \\
\hline NSW & 13 & $11.12(3.24)$ & $7.01-17.05$ & 10.85 & $84.6 \%$ \\
Vic & 19 & $14.30(2.24)$ & $10.00-17.30$ & 15.00 & $36.8 \%$ \\
WA & 25 & $12.12(3.25)$ & $7.02-17.54$ & 11.28 & $72.0 \%$ \\
\hline
\end{tabular}

For charges related to 28 complainants $(50 \%)$, the defendant was acquitted of all charges. For charges related to 10 complainants (18\%), the defendant was convicted on some charges, and 13 were convicted on all charges $(23 \%)$. Charges related to four complainants (7\%) resulted in a hung jury on all charges, and one trial resulted in a mistrial $(2 \%)$. For purposes of analyses, trial outcomes were collapsed into two categories: convictions for any charges (41\%), or none $(59 \%)$.

In all but two trials, the adult defendant was male. The defendant was a stranger in three trials $(6 \%)$, a familiar non-family member in 23 trials $(45 \%)$, a nonimmediate family member in 13 trials $(25 \%)$, and an immediate family member in 12 trials (24\%). In $24(47 \%)$ of the trials, the allegations were of repeated abuse. The most serious charge in one trial was a non-contact offence (eg, exposure), in $27(53 \%)$ trials it was a contact non-penetrative offence (eg, fondling), and in 23 trials $(45 \%)$ it was a penetrative offence. For purposes of analyses, the one noncontact offence was grouped with the non-penetrative offences. Children involved in cases with penetrative offences were older $\left(M_{\text {age }}=13.82, S D=3.39\right)$ than children involved in cases with non-penetrative offences $\left(M_{\text {age }}=11.83, S D=\right.$ $2.74),{ }^{100}$ but there were no age differences across levels of child-perpetrator relationship. ${ }^{101}$

\footnotetext{
$99 \quad F(2,53)=5.03, p=.01, \eta_{p}{ }^{2}=.16$.

$100 \quad F(1,54)=5.96, p=.018, \eta_{p}{ }^{2}=.10$.

$101 \quad F<1$.
} 


\section{Coding}

Coders blind to the purpose of the present study extracted the competence questions from the trial transcripts and coded them for format and type. Three question formats were distinguished: recall-based ('wh-' questions), and two types of forced-choice recognition questions (yes/no and specified options). It was also noted whether or not the question was presumptive (for example, 'You know the difference between truths and lies, right?' or 'So you'll tell the truth today, yes?'). Categories of competence questions were derived from a study by Evans and Lyon, ${ }^{102}$ which classified questions as meaning-based (the meaning of truth or lies) or morality-based (the morality of truth and lies). Table 3 provides examples of each type. In addition to the seven categories used by Evans and Lyon, an Obligation category was added that included all questions about the child's duty or intent to tell the truth in court (for example, 'Do you plan to tell the truth today?' and 'Do you think you will be able to promise to tell the truth?'). The eight categories were mutually exclusive.

Table 3: Codes for Truth-Lie Competence Questions

\begin{tabular}{|c|c|c|}
\hline Type & Category & Definition and Example \\
\hline \multirow[t]{4}{*}{ Meaning-based } & Definition & Requests explanation of key terms: 'What does the truth mean?' \\
\hline & Identification & $\begin{array}{l}\text { Exemplar of a concept: 'If I were to say my hair was green, would } \\
\text { that be the truth?' }\end{array}$ \\
\hline & Example & $\begin{array}{l}\text { Asks complainant to generate an example: 'Give me an example } \\
\text { of a lie'. }\end{array}$ \\
\hline & Difference & $\begin{array}{l}\text { Asks for comparative definition: 'What's the difference between } \\
\text { truth and lie?' }\end{array}$ \\
\hline \multirow[t]{4}{*}{ Morality-based } & Evaluation & Asks about value of key terms: 'Is it good or bad to tell a lie?' \\
\hline & Consequence & $\begin{array}{l}\text { Asks about outcomes of truths or lies: 'What do you think will } \\
\text { happen if you tell a lie?' }\end{array}$ \\
\hline & Prior occurrence & Asks about past behaviour: 'Have you ever told a lie?' \\
\hline & Obligation & $\begin{array}{l}\text { Asks about child's duty, intent to tell truth: 'Will you tell the truth } \\
\text { today?' }\end{array}$ \\
\hline
\end{tabular}

The accuracy of children's responses to the questions was coded as satisfactory (provides a correct answer, a reasonable description, such as 'the truth means you say what really happened', or acquiesces where a 'yes' response is expected), unsatisfactory (provides an incorrect answer, does not provide a reasonable description, or says 'no' where a 'yes' response is expected), or don't know, don't understand, and other (off-topic or nonsensical response).

102 Angela D Evans and Thomas D Lyon, ‘Assessing Children's Competency to Take the Oath in Court: The Influence of Question Type on Children's Accuracy' (2012) 36(3) Law and Human Behavior 195. 


\section{Reliability}

Question type, format, and accuracy were coded by the first author. A random subset of $15 \%$ of competence questions was double-coded by a research assistant who was blind to the hypotheses of the present study. Cohen's Kappa was 1.00 for question type, .96 for category, and .98 for accuracy; the two disagreements were resolved through discussion.

\section{B Results}

\section{Prevalence and Frequency of Competence Questions}

Across the sample of children, 249 competence questions were posed. Table 4 provides an overview of the number and average asked in each category. Just over one-third of the children $(35.7 \%, n=20)$ received no competence questions and almost two-thirds $(64.3 \%, n=36)$ were asked one or more. These children were asked $1-20$ competence questions $(M=6.92$ questions, $S D=4.57)$. The average number of competence questions asked did not differ significantly across jurisdiction: NSW $(M=3.92, S D=4.72)$, Vic $(M=3.42, S D=4.91)$, and WA $(M$ $=5.52, S D=5.08) .{ }^{103}$ Across all trials, only once was a child asked to provide an example of truth or lie, so this category was not considered further.

Table 4: Descriptive Results for Each Type of Competence Question

\begin{tabular}{lllll}
\hline Type of Question & $\boldsymbol{n}^{\mathrm{a}}$ & Range & $\boldsymbol{M}^{\mathrm{b}}$ & $\boldsymbol{S D}$ \\
\hline Definition & 10 & $1-6$ & 2.50 & 1.78 \\
Identification & 20 & $1-6$ & 2.55 & 1.23 \\
Difference & 18 & $1-2$ & 1.33 & 0.49 \\
Evaluation & 25 & $1-7$ & 3.12 & 1.69 \\
Consequence & 10 & $1-6$ & 2.50 & 1.72 \\
Prior Occurrence & 5 & $1-3$ & 2.60 & 0.89 \\
Obligation & 20 & $1-4$ & 1.65 & 0.88 \\
\hline
\end{tabular}

Note: ${ }^{a}$ Number of children asked at least one. ${ }^{\mathrm{b}}$ Mean number of questions calculated from children who were posed at least one.

Age at trial was negatively correlated with the number of competence questions asked. ${ }^{104}$ That is, older children were asked fewer questions and younger children were asked more questions. The mean age of children asked no competence questions was 14.81 years ${ }^{105}$ and the mean age of children asked one or more competence questions was 11.35 years. ${ }^{106}$ Independent-samples t-tests comparing the mean age of children posed one or more competence questions to

$103 \quad F(2,53)=1.06, p=.35, \eta_{p}^{2}=.04$.

$104 \quad r(54)=-.58, p<.001$.

$105 S D=2.93$.

$106 S D=2.62$. The difference between these groups was statistically significant: $t(55)=4.55, p<.001$. 
the mean age of children not posed any indicated that children posed a competence question were significantly younger for all types of questions ${ }^{107}$ except Definition. ${ }^{108}$ No gender differences emerged regarding whether or not each type of competence question was asked. ${ }^{109}$

\section{Question Format, Type and Response}

Out of 249 competence questions posed, $58.6 \%(n=146)$ were yes/no questions to which children could simply acquiesce (ie, say yes) and they answered satisfactorily $85 \%$ of the time. Another $10.4 \%(n=26)$ of questions were forcedchoice, and children chose the correct option $100 \%$ of the time. These results echo those in prior research demonstrating that children find the forced-choice questions easier to answer. Responses of children to the $30.9 \%(n=77)$ of recall-based questions were satisfactory $51 \%$ of the time. Table 5 displays the question format for each type of competence question.

Definition questions were often worded as 'wh-' questions, such as, 'What does telling the truth mean?' Children provided a satisfactory response to definition questions only $36 \%$ of the time. Conversely, Identification questions were often worded as recognition questions, with forced-choice options (such as, 'If I said I was wearing a floppy hat, would that be the truth or a lie?') asked more frequently than yes/no questions. Children answered all Identification questions very accurately, providing a satisfactory response $80 \%$ of the time. Difference questions were overwhelmingly yes/no, and in many cases they were presumptive. The most common format was, 'You know the difference between a truth and a lie, don't you?'

Evaluation questions were most often worded as yes/no questions (for example, 'Is it important to tell the truth?'), as were Prior Occurrence questions (for example, 'Have you ever told a lie?'). Few Consequence questions were asked but they were equally distributed between 'wh-' (for example, 'What will happen if you tell a lie?') and yes/no questions (for example, 'Will you be in trouble if you tell lies here?'). A large proportion of children (85\%) answered Evaluation questions satisfactorily, fewer answered Prior Occurrence questions satisfactorily $(62 \%)$ and less than half answered Consequence questions satisfactorily (48\%).

Obligation questions were most often worded as yes/no questions (for example, 'Will you tell the truth today?'). Approximately one-third ( $n=7)$ of the 20 children who were posed questions in this category were asked some version of the promise to tell the truth. The remainder were asked questions such as, 'Are you planning to tell the truth today?', 'Will you only tell what really happened and not make up any stories?' and 'When you're asked questions today what are you going to do?' (after a discussion about truth-telling). Most children (94\%) answered Obligation questions satisfactorily.

Individual correlations between children's age and question types were not conducted because of the high number of tests and few contributing data points in

$107 t \mathrm{~s} \geq 2.35, p \mathrm{~s} \leq .023$, Cohen's $d \mathrm{~s} \geq .59$.

$108 t(54)<1, p=.36$, Cohen's $d=.34$.

$109 \chi^{2} \mathrm{~s}(1, N=56)<2$. 
some analyses. The total number of presumptive questions asked was unrelated to children's age, ${ }^{110}$ but the proportion of presumptive questions was positively related. ${ }^{111}$ As the age of the children increased, the competence questions posed to them were increasingly likely to be presumptive. Across all categories, 40 presumptive questions were posed (16.1\% of all questions asked), and children acquiesced to every one.

Table 5: Descriptive Results for Question Format by Competence Category

\begin{tabular}{llllll}
\hline Category $(n)$ & 'Wh-' question & YN & FC & Presumptive $^{\mathrm{b}}$ & Prop Sat $^{\mathrm{c}}$ \\
\hline Definition $(n=10)$ & $.60^{\mathrm{a}}$ & .38 & .02 & -- & .36 \\
Identification $(n=20)$ & .20 & .37 & .44 & .03 & .80 \\
Difference $(n=18)$ & .25 & .75 & -- & .33 & .83 \\
Evaluation $(n=25)$ & .19 & .75 & .05 & .15 & .85 \\
Consequence $(n=10)$ & .51 & .48 & .02 & .08 & .48 \\
Prior Occurrence $(n=5)$ & .13 & .87 & --- & .07 & .62 \\
Obligation $(n=20)$ & .11 & .83 & .06 & .20 & .94 \\
\hline Proportion satisfactory ${ }^{\mathrm{a}}$ & .53 & .82 & 1.00 & 1.00 & \\
\hline
\end{tabular}

Note: 'Wh-' question (eg, 'What does it mean to tell the truth?'), YN = yes/no question (eg, 'If I said my hair was purple am I lying?'), FC = forced-choice question (eg, 'Must you tell truths or lies here today?'). a Proportions calculated out of total for each question type (the first three columns each sum to 1.00). ${ }^{\mathrm{b}}$ Proportion presumptive is calculated within each category. $\mathrm{c}$ Prop Sat $=$ proportion satisfactorily/correctly answered.

The total number of competence questions asked did not differ significantly across jurisdictions: NSW $(M=3.92, S D=4.72)$, Vic $(M=3.42, S D=4.91)$ and WA $(M=5.52, S D=5.08) .{ }^{112}$ However, there were some jurisdictional differences in the categories of competence questions used. Identification questions were most commonly asked in WA and almost never asked in NSW. ${ }^{113}$ Evaluation questions were asked more often than would be expected by chance in WA and less often in Vic. ${ }^{114}$ This may be because the Evidence Act 1906 (WA) places an explicit emphasis on the witness understanding the seriousness of the matter (where the witness is aged under 12 years and giving sworn evidence) or that the witness will be liable to punishment if he or she does not tell the truth (where the witness is aged 12 years and over and giving unsworn evidence), thus raising questions about the morality of telling the truth not contained with the Uniform Evidence Law. There was no significant jurisdictional difference in the proportion of questions posed in a presumptive manner. ${ }^{115}$

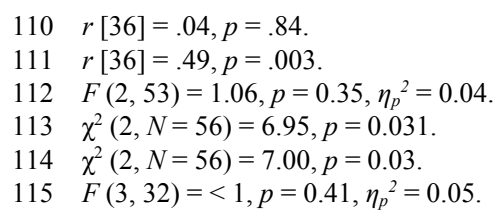




\section{Sworn and Unsworn Evidence}

In all, $82 \%(n=46)$ of children gave sworn testimony: $47.8 \%(n=22)$ took an oath and 52.2\% $(n=24)$ were affirmed. Nine children $(16 \%)$ testified unsworn and data were missing for one child. In WA, seven children (28\%) testified unsworn, compared to just one child in NSW (8\%) and one child in Vic (6\%). A chi-square analysis on sworn versus unsworn testimony revealed no significant difference across jurisdictions. ${ }^{116}$

All nine unsworn children were 12 years of age or younger. An independentsamples $t$-test indicated that children who did not take the oath or affirmation were significantly younger $(M=9.05, S D=1.62)$ than children who were sworn $(M=$ 13.27, $S D=2.90) .{ }^{117}$ On average, unsworn children were asked $10.44(S D=7.30)$ competence questions, significantly more than children who were sworn $(M=$ $4.47, S D=5.16){ }^{118}$

Because the law in WA separates children under the age of 12 from those aged 12 and over with respect to the competence inquiry, we created a variable to split all children in the sample along this dichotomy to explore potential age by jurisdiction interactions. We conducted a 2 (age group) x 3 (jurisdiction) ANOVA on the number of competence questions asked. The only significant effect was for age group. ${ }^{119}$ Children 12 years of age and younger were asked more than six times as many competence questions $(M=8.24, S D=5.91)$ as children over 12 years $(M$ $=1.18, S D=1.94)$. No other effects were significant. ${ }^{120}$

Bearing in mind that younger children were more likely to be asked competence questions and less likely to have been sworn or affirmed, the following significant differences in the types of competence questions were observed: Evaluation $^{121}$ and Prior Occurrence. ${ }^{122}$ In both cases, children who testified unsworn were more likely to be asked these types of questions than children who were sworn. It is perhaps more notable that, for the other question types, there were no differences in the likelihood of being asked these types of competence questions as a function of having been sworn or not. ${ }^{123}$

\section{Competence and Case Characteristics}

There were no relationships between perpetrator identity and the types of competence questions asked, ${ }^{124}$ or the number of questions asked. ${ }^{125} \mathrm{We}$ intended to assess competence questions across levels of offence type (penetrative or not), but these analyses were complicated by the fact that significantly more cases with penetrative offences $(n=23)$ involved older complainants $\left(M_{\text {age }}=13.82, S D=\right.$

\footnotetext{
$116 \chi^{2}(2, N=56)=4.79, p=.09$.

$117 \quad t(53)=4.22, p<.001$, Cohen's $d=1.57$.

$118 t(53)=2.91, p=.005$, Cohen's $d=1.10$.

$119 \quad F(1,50)=18.56, p<.001, \eta_{p}{ }^{2}=.27$.

$120 \quad F \mathrm{~s}<1, p \mathrm{~s}>.38, \eta_{p}^{2} \mathrm{~s}<.04$.

$121 \chi^{2}(2, N=55)=10.91, p=.004$.

$122 \chi^{2}(2, N=55)=7.65, p=.022$.

$123 \quad \chi^{2} \mathrm{~s} \leq 5.35, p \mathrm{~s} \geq .069$.

$124 \quad \chi^{2} \mathrm{~s} \leq 4.17, p \mathrm{~s} \geq .12$.

$125 F<1$.
} 
3.39) than those with non-penetrative offences $\left(M_{\text {age }}=11.83, S D=2.74\right) .{ }^{126}$ As such, initial analyses suggested that fewer competence questions were asked in cases with penetrative charges $(M=2.96, S D=4.26)$ than with non-penetrative charges $(M=5.52, S D=5.20)$, but when a 2 (Offence type: Non-penetrative, Penetrative) ANCOVA with age in years covaried was conducted, the difference was non-significant. ${ }^{127}$

\section{DISCUSSION AND IMPLICATIONS OF THE FINDINGS}

\section{A Appropriateness of Competence Questioning}

The format of questions posed to children is widely acknowledged to influence their response accuracy, but the interpretation of those effects may differ depending on the questioner's goal. In children's memory research, recall questions are preferred over recognition questions. Although they are more challenging, they give a better indication of what children actually know and remember. In a competence inquiry, if questions are primarily recall-based, children are likely to perform poorly because they do not know how to answer questions about abstract concepts on truths and lies. The findings in this study were that children provided satisfactory responses to recall-based questions only half of the time.

The most common question format used in court was recognition questions, indicating judges are largely using developmentally appropriate questioning styles. However, $30.9 \%(n=77)$ of questions asked by judges were recall questions. This finding suggests some competence inquiries are not being conducted in a developmentally appropriate manner. Where children are asked less appropriate questions, they may be less able to demonstrate their knowledge of truth and lies, and as a result, a judge may underestimate their competence.

Where children were questioned about the meaning of truth and lies, Identification and Difference questions were asked more frequently and Definition questions were asked less frequently. Identification questions are arguably the easiest category of competence question, and the children in this sample answered the majority of these questions correctly. Providing definitions and explanations of the difference between truths and lies is more developmentally advanced. Accordingly, it is perhaps unsurprising that Definition questions were answered satisfactorily by children only $36 \%$ of the time. Children fared better on Difference questions, answering these questions satisfactorily $83 \%$ of the time. This finding can likely be explained by the fact that these questions were often posed as yes/no questions; if they had been asked as recall questions, the number of children answering them satisfactorily may have decreased. As such, this finding demonstrates the importance of considering both question type and question format when phrasing a question for a child's competence inquiry.

$126 \quad F(1,54)=5.96, p=.018, \eta_{p}{ }^{2}=.10$.

$127 F<1, p=.48, \eta_{p}{ }^{2}<.01$. 
Some of the questions children were asked were counter-intuitive. For example, five children were posed Prior Occurrence questions, and $62 \%$ of these were answered satisfactorily. However, to answer a Prior Occurrence question satisfactorily, a child needed to admit to having previously told a lie. ${ }^{128}$ Children might be reluctant to admit to having previously lied when they are questioned by an authority figure in the context of a discussion about the need to tell the truth. Thus, children asked Prior Occurrence questions are presented with two options: admit to having previously lied or lie about having previously lied. While such questions may be asked by a judge or lawyer to set up a discussion about the potential consequences of lying, both answers have the potential to detrimentally impact perceptions of the child's credibility.

Ultimately, this study observed that the questions used by judges were largely in line with best practice. However, there are areas where questioning may not be developmentally appropriate for the witness and thus risks underestimating their competence. Such underestimation is particularly troubling in those jurisdictions that require witnesses to demonstrate knowledge about truth and lies to give unsworn evidence (as opposed to being instructed about certain matters as the condition for competence) and where unsworn evidence may be given less probative weight than sworn evidence. In these jurisdictions, erroneous determinations as to a witness' competence (or lack thereof) may result in the witness' evidence either being given less weight or being excluded altogether, with a likely significant impact on the outcome of the trial.

With respect to the number of questions children were asked, this study found older children were asked fewer competence questions and younger children were asked more competence questions. Further, older children were more likely to testify by oath or affirmation, while younger children were more likely to testify unsworn. These findings suggest younger children are being asked more competence questions because it is more difficult to determine whether they satisfy the test for sworn evidence. All jurisdictions require the court to find that a child is not competent to give sworn evidence before the issue of unsworn evidence can be considered. However, this indicates more questioning is required of younger children, who struggle more to answer competence questions. As mentioned above, competence inquiries have the potential to make children feel confused and thus appear less credible before they have even begun to testify.

In light of these findings, it is worth considering the value of retaining competence questioning and a distinction between sworn and unsworn evidence. As previously discussed, the Royal Commission's recommendation is unclear on this point, but appears to suggest the retention of sworn and unsworn forms of evidence. However, this distinction is not inevitable. Canada removed the categories of sworn and unsworn evidence for children under the age of 14 by banning the questioning of witnesses as to their understanding of truth and lies. The Canadian approach addresses the issues of the underestimation of children's

128 In line with Evans and Lyon (n 102), an answer was recorded as satisfactory if it was in line with reasonable assumptions - meaning that the satisfactory answer to the question, 'Have you ever told a lie?' would be 'yes'. 
competence through developmentally inappropriate questions and of children being overwhelmed by competence questions prior to testifying. Further, such an approach would address the situation in some Australian jurisdictions where children's evidence is potentially given less probative value because it is unsworn. A general warning about the probative value of unsworn would no longer be applicable, although judges would presumably retain the ability to give a warning where warranted by the specific factual circumstances of particular cases. ${ }^{129}$

The foregoing analysis suggests there is great merit to the Canadian approach and policymakers should consider following the example of Canada when legislating to implement the Royal Commission's recommendation. However, in the event such reforms are not adopted, judges should use best practice questions when determining the competence of child witnesses. The Equality before the Law Bench Book provides guidance on conducting competence questioning. ${ }^{130}$ Further, judicial training and education plays a key role in enabling judges to recognise and ask developmentally appropriate questions.

\section{B Promise to Tell the Truth}

As previously stated, competence to give sworn evidence does not guarantee that a witness will testify truthfully. Psychological research indicates that asking a child to promise to tell the truth increases the likelihood that the child will comply. However, only $35.7 \%(20 / 56)$ of children examined in this study were asked a question in the obligation category, and only one-third of them $(n=7)$ were delivered a 'promise' question resembling the format recommended by researchers, such as, 'Will you promise to tell the truth?'

The Royal Commission recommended that a child who is not competent to give sworn evidence should be asked to promise to tell the truth in order to give unsworn evidence. In this article, we have highlighted the benefits of abolishing a distinction between sworn and unsworn evidence, in which case all children under a certain age would be asked to promise to tell the truth, in line with best psychological practice. However, assuming a distinction between sworn and unsworn evidence is retained in Australian jurisdictions, the Royal Commission's recommendation will enhance the likelihood that children will testify truthfully.

\section{CONCLUSION}

The central role of children's evidence in sexual abuse proceedings is increasingly recognised. Where the child is the sole witness to the abuse, their evidence is crucial to secure a conviction. Accordingly, in recent years a number of innovations have been introduced in Australian courts to assist children to communicate their evidence, including the use of special measures, such as the use of pre-recorded evidence, and the introduction of witness intermediaries. The time

129 For example, as was warranted in RPM v The Queen [2004] WASCA 174.

130 Judicial Commission of New South Wales (n 48) 6.3.2. 
is ripe to consider whether the competence regime is appropriate for its purpose and how it could be reformed to better respond to the needs of child witnesses.

The Royal Commission recommendation addresses some of the issues with the current competence laws in Australia. However, the recommendation is ambiguous as to questioning to determine competence to give sworn evidence. As the findings of this study show, this is an area where current judicial practice may fall short of what is developmentally appropriate for children. Given the potential negative consequences of underestimating a child's competence to give sworn evidence, and the fact that the competence inquiry itself could induce confusion in a witness or jeopardise their credibility before a trial has even begun, this article expanded on the Royal Commission recommendation by suggesting that there may be utility in following the Canadian approach and abolishing inquiries into truthlie competence altogether. Instead of testing witnesses as to their competence to give sworn or unsworn evidence, witnesses would simply be required to promise to tell the truth after their basic competence to testify has been established. 